"Mircea cel Batran" Naval Academy Scientific Bulletin, Volume XIX - 2016 - Issue 1

Published by "Mircea cel Batran" Naval Academy Press, Constanta, Romania // The journal is indexed in:

PROQUEST / DOAJ / DRJI / JOURNAL INDEX / I2OR / SCIENCE LIBRARY INDEX / Google Scholar / Crossref /

Academic Keys / ROAD Open Access / OAJI / Academic Resources / Scientific Indexing Services / SCIPIO

\title{
ETHICS AND PROFESSIONALISM IN SPORTS MANAGEMENT ACTIVITIES
}

\author{
Elena HANU ${ }^{1}$ \\ Silvia TEODORESCU² \\ Carmen ENE-VOICULESCU ${ }^{3}$ \\ ${ }^{1}$ Prof.Dr. National College Mihai Eminescu Constanta \\ ${ }^{2}$ Professor PhD, UNEFS Bucharest \\ ${ }^{3}$ Professor PhD, Ovidius University, Faculty of Physical Education and Sport, Constanta
}

Abstract: Defining the elements pertaining to the scale and diversity of sports activities, the specificity and complexity of the Organization, management, and evaluation of the results.

Keywords: Ethics, professionalism, performance, management, sport activities.

\section{INTRODUCTION}

Sports as universal language of all nations with its spirit teaches us to leave something behind us, to be stronger, more dignified and more correct.

Sports interacts at all times with the other subsystems of social life, it transforms into a particularly comprehensive phenomenon, bringing under its scope millions of individuals, with different historical and cultural background.

The international development of sports in the past few years, with the theoretical and practical concerns in the field of sports organisations management, reveals a direction toward the study of management processes and relations in organisations, for the development of new systems, methods and techniques of management that would ensure more effective sports activities and the increase of competitiveness. As a result, the subject of this paper addresses one of the sensitive parts of the management of sporting activities.

\section{ESSAY CONTENT}

Present sports trends require the use of management to ensure an interconnection of the structures and activities. The management applied in sports contributes to establish full functionality of sports structures, human resources and a multitude of means, objectives and intentions. Through sports management the individuals' efforts are coordinated to achieve a common goal. Therefore, the management in sports helps to master and control both situations as well as complex systems, while ensuring a continued management for the multitude of sporting activities designed to generate efficiency. Scientifically defining management as "a system of actions carried out in order to ensure the normal functionality and efficiency of the organisation as a whole, as well as the component structures" (V. Cornescu, I. Mihailescu, S. Stanciu, 2003), completed by specifying that this complex of operating actions have a foundation of all the theoretical and methodological elements specific to the science of management, we may use the expression "effective management", as a creative act of adaptation to the organisational characteristic, promotion and use of the various management techniques and methods to achieve the objectives. The essence of management is expressed by two components, on the one hand the scientific component represented by the exact understanding of the principles, rules, methods and techniques, and on the other hand the art component, attribute conferred directly to the manager's excellence, pragmatism and the ability to apply specific knowledge in order to achieve the organisation's goals.

The special features of management in sports also consist of the fact that they apply to all forms of sporting activities, all sports disciplines, ensuring an organized participation, leading to better results. The management process has a cyclic nature and the management relationships inside the sports organisations are determined by a number of variables related to: the nature of the legal person (public/private); the category of sport structure (individual/team sports); the human potential (technicians, sportsmen, other categories of personnel); and the manager's vision regarding the promoted management style.

Regarding the organisational structures of the physical education and sport system, a vast reforming process can be observed in the past few years. As a result the organisational forms were developed based upon clear principles, which provide appropriate relations between governmental sport structures and nongovernmental organisations, thus ensuring the efficiency of sporting activity's mass and performance.

Sports organisations need to have a creative manager, flexible in his thinking and actions, receptive to all of the organisation's actions and 


\begin{abstract}
"Mircea cel Batran" Naval Academy Scientific Bulletin, Volume XIX - 2016 - Issue 1
Published by "Mircea cel Batran" Naval Academy Press, Constanta, Romania /I The journal is indexed in: PROQUEST / DOAJ / DRJI / JOURNAL INDEX / I2OR / SCIENCE LIBRARY INDEX / Google Scholar / Crossref /

Academic Keys / ROAD Open Access / OAJI / Academic Resources / Scientific Indexing Services / SCIPIO
\end{abstract}

very well trained, both in the management field, as well as in the psychosocial field.

Achieving great performance, starting at the level of children and up to the top of the pyramid, is no longer valid without creating a series of maximum necessity conditions to completely solve the problems imposed through making the training process more efficient, providing the best managerial and scientific assistance.

Professionalism and ethics in sporting activities management are represented by the diversity and the level of participants' training in sporting activities in Romania.

Ethics in the management of sporting activities is a complex and complicated matter. This topic is hard to explain and understand, since, in our century, ethical codes have changed, and the feeling that morality is "relative" has increased. Given the diversity in the field of sports activities, new ethical references are necessary. The management action in sports means professionalism and professionalising, competitiveness and performance, practical activity as well as intrinsic and extrinsic motivation with respect to this field. This managerial labour professionalising has a dual significance; on the one hand regarding the basic profession, and on the other hand regarding the level of knowledge in the field of management science and the level of skills required for their application.

Ethical principles relate to people's current conduct, habits and attitudes for the general concepts of good and bad, truth or lies, equity and discrimination, freedom and stress (Popa, I.; Filip, $R$, 1999). Promoting the managers' appropriate ethical behaviour has a major importance, with decisive impact for the final results of the entire organisation.

Ethics in management shows how an organisation integrates the fundamental values in the policies, standards, but also in the decision making process. These values, such as: respect, trust, fairness and honesty are ethical constructions which are intended to become behavioural rules, values, attitudes, on the basis of which it is possible to further assign motivation, norms and principles.

Ethics represents a profound insight into moral aspects and connotations of a person's actions and decisions in the society.

The organisations and individuals are "moral agents", establishing missions, targets, represent the organisation as a corporate entity, which acts, operates and is assessed based on moral standards, relating to the effects their actions.

It is very important to specify the fact that the organisations are not self-ruled. They are coordinated, managed and directed towards their mission and objectives by a person or group of people. Any organisation needs a leader, a manager, a key person, creating the structure and the system to support "the statement of values" for the organisation.

The manager must be this person who shapes the system of values and norms, he has to be the model of thought, action and emotion for all the members of the organisation to accept, to understand, to learn, in their common effort to fulfil their mission and to improve.

All the efforts in the ethics direction represent actual "defence shields" for the change pressures faced by sport systems, all the more so the Romanian system. A moral, ethical manager is one that is not driven only by the desire to achieve outstanding results, but uses a set of appropriate means to achieve them, striving to achieve a fair balance between the interests of the management of the group, the leader's personal interest and the society's interest in general.

Ethical conduct in managerial activity is reflected in compliance with a combination of principles and rules, leading together to the preservation of pristine social values. These rules for the managerial activity imply:

$>$ Integrity - the persons involved in the management process must be honest, correct and incorruptible;

$>$ "The sovereignty of the law" - the persons involved in the management process shall ensure that any decision in the leading process will be based upon the principle "the law is sovereign".

$>$ Professional competence - the persons involved in the management process have to fulfil their work duties with professionalism, competence, impartiality.

$>$ Responsibility - the persons involved in the management activity must realize that there are liable for all actions performed by them in the name of the organisation they lead.

$>$ Consistency - the persons involved in the management process will be driven toward fulfilling specific activities correctly, ethically and accessible to all the other parties involved in the process. Managers will be consistent in their own administrative behaviour and will competently respond to the reasonable and founded expectations of the direct and indirect beneficiaries pertaining to his activity.

$>$ Loyalty to the organisation is taking shape by reciprocal obligations: organisation - collaborator / employee, by assigning roles and responsibilities. There 


\begin{abstract}
"Mircea cel Batran" Naval Academy Scientific Bulletin, Volume XIX - 2016 - Issue 1
Published by "Mircea cel Batran" Naval Academy Press, Constanta, Romania /I The journal is indexed in: PROQUEST / DOAJ / DRJI / JOURNAL INDEX / I2OR / SCIENCE LIBRARY INDEX / Google Scholar / Crossref /

Academic Keys / ROAD Open Access / OAJI / Academic Resources / Scientific Indexing Services / SCIPIO
\end{abstract}

is a moral element: the pride for their own programs, activities and team spirit, care for the organisation's welfare, the attachment to colleagues.

The current context of the economic development, the internal transformations of the sports organisations, require a change in the classical attitude with respect to the achieved results and performance in ordinary activities. The European sports competition requires the relationship between performance and result to represent a connecting "bridge", to place the sports organisation in a favourable position in relation to the main competitors. If the results define and measure the performance, the spectrum of the organisation's performance is much more complex, including other "performances", such as managerial, economical, technological, and involvement performance in society.

The assessment and evaluation of sports organisations cannot overlook economic and social performance. In this context, the social issue remains a main concern for the current activity of sports organisations that want to accept performance and to generate performance.

The whole adjustment process with the European requirements and the development of sports, society and modern sports management systems, appoint the manager as the "binder" with the capacity and power to bring all of these elements to a common denominator. Increasing the degree of professionalism in leading, regardless of the social and economic context, represents one of the main lines for current development. In this context, an efficient managerial relationship is conclusive with respect to the performance and quality of the provided services. Increasing quality is based upon added value, i.e. it depends on what the organisation, with its programs and activities, added to the "heritage" of knowledge, skills, attitudes and general competencies available at the individual, group and community level.

Nowadays, in the Romanian sport, the stage of quality assurance is becoming more and more a certain and necessary means for labelling and grading the sports institutions / organisations in a permanent constructive competition with themselves and with others, in a context where the European Union policy is directed to promote quality, drafting the White Paper concerning the Single European Market ("Growth, competitiveness, employment - challenges and ways forward into the $21^{\text {st }}$ century"). This document was followed by "European Quality Promotion Policy or The European Way towards Excellence", which includes a strategic vision on quality. This vision involves taking into consideration two categories of requirements:

$>$ Requirements of external environment requirements of the consumer and society relating to the quality of life;

$>$ Requirements of the organisation's internal environment relating to efficient processes and development of human resources.

The philosophy of management should aim to make morality compatible with specific purpose. The management process is subject to norms/rules to define the "game". Compliance with the "rules of the game", when these are rational and stimulate, is sufficient to define professionalism in "management ethics".

One of fundamental errors of the Romanian society consists of the overlapping and confusion between institution/organisation, generally called management. As a result, the false idea that in order to lead an organisation it is sufficient to have the necessary capital and a recipe for winning. But being manager/leader means: to have a project or more than that, a vision and to develop that project as means for a profit activity in accordance with the provisions of the law and in compliance with the interests of the community; to develop strategies, that is, to design that idea in time, predicting its evolution and other people's expectations; to plan, to establish the activity in stages, with precise time limits and objectives; to organize, that is, to create departments with specific and precise tasks, subject to the same objective; and, finally, to communicate, meaning to promote the offer and its values, and to understand the interests of the direct and indirect beneficiaries. (D. Gusti, 1998).

\title{
CONCLUSIONS
}

In Romania, sports management has been approached quite late, after the year 1995, most research papers and publications brought knowledge in the field, showing aspects of this activity (Lador I., I, Frâncu, E., Hoffman, A., Ganera, C., Mihăilescu, N., et al.) at different levels and in different situations, going beyond the sports organisations area, and their problems. Nevertheless, there are common points of view allowing us to conclude that the development of sport activities does not concern only structure, procedures, and systems within the organization of sports ,but also abstract factors, such as: leading style, team work, collaboration between different services or technical departments, staff motivation, without neglecting the problems of power and influence, coordination and conflict occurring inside an organisation, regardless of the type of provider organization. 
"Mircea cel Batran" Naval Academy Scientific Bulletin, Volume XIX - 2016 - Issue 1 Published by "Mircea cel Batran" Naval Academy Press, Constanta, Romania // The journal is indexed in: PROQUEST / DOAJ / DRJI / JOURNAL INDEX / I2OR / SCIENCE LIBRARY INDEX / Google Scholar / Crossref / Academic Keys / ROAD Open Access / OAJI / Academic Resources / Scientific Indexing Services / SCIPIO

\section{BIBLIOGRAPHY}

[1] Cartea Albă, Creștere, competitivitate, angajare-provocări și căi spre secolul 21 (White Paper, Growth, Competitiveness, Employment - Challenges and Ways forward into the 21 ${ }^{\text {st }}$ Century), 1994

[2] V. Cornescu, I. Mihăilescu, S. Stanciu, 2003, Managementul organizaţiei (Organisation Management), Publishing House ALL BECK, Bucharest

[3] Gusti, D., 1998, Idealul etic şi personalitatea (Ethical Ideal and Personality), Publishing House Floare Albastră, Bucharest

[4] Popa, I.; Filip, R., 1999, Management international (International Management), Publishing House Editura Economică, Bucharest

Politica europeană de promovare a calităţii (European Quality Promotion Policy), 1995

Nationally we reveal more authors and reference material which have decisively influenced other published papers or articles: Virgil Voicu - „Legislaţia şi managementul în educaţie fizică şi sport” (Legislation and Management in Physical Education and Sports) (1995), loan Lador şi Virgil Voicu - „Elemente de management şi legislaţie sportivă" (Management and Sports Legislation Elements) (1996), Alexandru Lăzărescu - „Management în sport” (Management in Sports) (1998), Ioan Lador - „Bazele teoretice ale managementului în sport" (Theoretical Basics in Sports Management) (2000), M. Mioc „Interdisciplinaritatea conceptului de management şi definirea statutului de manager în activitatea sportivă” (The Interdisciplinary Concept of Management and Defining the Manager Status in Sports Activity), $F$. Moraru, M. Neamţu - „Management şi legislaţie în sport” (Management and Legislation in Sports) (2001), F. Balaiş, C. Mereuţă, C. Hânsă - „Managementul sportului” (Sports Management), Elena Frîncu „Managementul activităţii sportive” (The Management of Sporting Activity) (2003), , Nicolae Mihăilescu „Management, marketing, legislaţie în activitatea sportivă” (Management, Marketing, Legislation in Sporting Activity) (2006) et al. 